\title{
Chlamydia psittaci in captive blue-and-gold macaws (Ara ararauna) in a triage center of wild animals in Brazil*
}

\section{Chlamydia psittaci em araras-canindé (Ara ararauna) cativas em um Centro de Triagem de Animais Silvestres no Brasil}

\author{
Tassia Cristina Bello de Vasconcelos, ${ }^{* *}$ Denise Monnerat Nogueira, ${ }^{* * *}$ Virginia Léo de Almeida Pereira, ${ }^{* * * *}$ \\ Elmiro Rosendo do Nascimento, ${ }^{* * * *}$ Sávio Freire Bruno**
}

\begin{abstract}
Chlamydia psittaci infection stands out due to its zoonotic potential. It was detected in several orders, being Psittaciformes its main reservoir. Our objective was to investigate the occurrence of $C$. psittaci infection by clinical and environmental examination, as well as agent detection by Polymerase Chain Reaction (PCR) from choanal and cloacal swabs in 46 blue-and-gold macaws (Ara ararauna) allocated at the Triage Center of Wild Animals, Brazilian Institute of Environment and Renewable Natural Resources, Rio de Janeiro state, Brazil. The frequency of positive detection of the bacteria found was $50 \%(23 / 46)$ by cloacal swab. In this percentual, $26.09 \%$ (12/23) were also positive by choanal swab, being the probability of detection 2.83 times higher for cloacal swabs when compared to choanal ones $(p<0.05)$. There was no association between body condition, temperature variations and PCR positivity for C. psittaci, being $34.78 \%$ of positive individuals asymptomatic to this disease. Therefore, our findings show agent's dispersion at the squad and high frequency of asymptomatic birds. Considering the possibility of contagion to workers and free living birds, the quarantine in wildlife conservation and support centers, as well as the care with hygiene and individual protection for humans who deal with the animals, should be strictly followed even in the absence of clinical signs.
\end{abstract}

Keywords: Chlamydiosis, birds, infection.

\begin{abstract}
Resumo
Infecções por Chlamydia psittaci destacam-se devido ao seu potencial zoonótico. Tal agente foi detectado em diversas ordens, sendo Psittaciformes seu principal reservatório. Objetivando-se demonstrar a ocorrência de tal processo infeccioso, procedeu-se investigação clínica e ambiental, associada à detecção do agente etiológico por Reação em Cadeia da Polimerase (PCR), a partir de swabs de coana e cloaca de 46 araras-canindés (Ara ararauna) pertencentes ao Centro de Triagem de Animais Silvestres do Instituto Brasileiro de Meio Ambiente e Recursos Renováveis, Rio de Janeiro, Brasil. Obteve-se uma frequência de detecção de $50 \%$ (23/46) a partir de swabs de cloaca. Entre esses, $26.09 \%$ (12/23) foram também positivos por meio de swab de coana, sendo a probabilidade de detecção 2,83 vezes maior a partir de swabs de cloaca que de coana ( $p<0.05$ ). Não houve associação entre condição corporal, variação de temperatura e detecção do agente por PCR, sendo $34,78 \%$ dos indivíduos positivos assintomáticos. Portanto, nossos resultados demonstram a dispersão do agente no plantel e alta frequência de assintomáticos. Devido à possibilidade de contágio para trabalhadores e aves de vida livre, a quarentena nos centros de suporte e conservação da vida silvestre, assim como os cuidados com higiene e proteção individual para com os trabalhadores que lidam com os animais devem ser seguidas rigidamente, mesmo na ausência de sinais ou sintomas nas aves.
\end{abstract}

Palavras-chave: clamidiose, aves, infecção.

\section{Introduction}

Chlamydia psittaci is a highly contagious zoonotic pathogen (Gerlach, 1994). It has been considered to be the main causative agent of chlamydiosis in birds, although there are two new Chlamydia species recently detected, C. gallinacea in breeding birds and C. avium in wild birds (Guo et al., 2016; SzymańskaCzerwińska and Niemczuk, 2016; Sachse et al., 2014).

This bacterium can cause systemic disease clinically evident in many mammals, reptiles, amphibians and birds. In the Avian class, C. psittaci was diagnosed by agent detection or serology, in at least 469 species of free-living or company birds (Kaleta e Taday, 2003). In these animals, the agent produces a systemic infection, which can vary according to bacterial strain and host susceptibility, which also include the possibility of asymptomatic infection (Sareyyupoglu et al., 2007).

Admittedly, Psittacidae birds are the largest reservoir of $C$. psittaci (Harkinezhad et al., 2009) and the close contact between humans and representatives of the Psittacidae family (Sigrist, 2006), particularly as pets, justifies the study of C. psittaci in these birds. Besides its public health importance (Harkinezhad et al., 2009), it also plays a role in ecosystem health, since

${ }^{*}$ Recebido em 6 de janeiro de 2015 e aceito em 16 de junho de 2016.

**Universidade Federal Fluminense, Programa de pós-graduação em Medicina Veterinária, Niterói, RJ, Brazil.

***Universidade Federal Rural do Rio de Janeiro, Instituto de Ciências Biológicas e da Saúde, Departamento de Genética, Seropédica, RJ, Brazil.

****Universidade Federal Fluminense, Faculdade de Veterinária, Departamento de Medicina Veterinária Coletiva e Saúde Pública, Niterói, RJ, Brazil.

Author for correspondence: E-mail: saviofreirebruno@id.uff.br. 
there is the risk of environmental contamination when occurs the release of individuals held temporary in captivity (ICMBIO, 2004). Therefore, chlamydiosis monitoring by agent detection or serology is mandatory in cases of bird release or exchange of ones (IBAMA, 2008).

Among Psittacidae birds, the blue-and-gold-macaw (Ara ararauna Linnaeus, 1758) has been heavily commercialized (Birdlife International, 2012). In Brazil, when there is an illegal sale intercepting of these animals, they are sent to the Triage Centers of Wild Animals (IBAMA, 2012). This procedure plays a role in screening and controlling of chlamydiosis, as overcrowding at institutions that receive them contributes to symptomatic appearance (Efe et al., 2006). The stress due to overpopulation in captivity predisposes to infection by $C$. psittaci and can contribute to the activation of latent infections and their spread in the squad (Raso et al., 2004).

Therefore, this work aimed to investigate the occurrence of $C$. psittaci in 46 macaws (Ara ararauna) allocated in the Centro de Triagem de Animais Silvestres - CETAS (Triage Center of Wild Animals), Rio de Janeiro state, Brazil, belonging to Instituto Brasileiro do Meio Ambiente e Recursos Naturais Renováveis - IBAMA (Brazilian Institute of Environment and Renewable Natural Resources).

\section{Materiais and methods}

We investigated 46 blue-and-gold macaws, Ara ararauna species (Birds: Psittaciformes), housed in five collective places (Figure 1) in CETAS / RJ (IBAMA), Seropédica city, Rio de Janeiro, Brazil, from July to October of 2011.

By physical contention, we accessed the following parameters: body condition (score), body temperature and specific inspection of natural cavities. The ophthalmic, nasal, hearing, oral and cloacal regions were examined. The body scores ranged from 01 to 05 , corresponding to "cachectic", "thin", "normal", "overweight" and "obese", respectively, according to pectoral musculature evaluation. The temperature of the birds was measured using a digital thermometer with gold sensor (Geratherm ${ }^{\circ}$ ), detection range from $32.0^{\circ} \mathrm{C}$ to $42.9^{\circ} \mathrm{C}$, resolution of $0.1^{\circ} \mathrm{C}$ and a maximum error of + or $-0.2^{\circ} \mathrm{C}$, according to the manufacturer.

The macroscopic features of faeces and urine aspects were evaluated through their visualization on brown paper previously placed on the floor under the roosts of enclosures.

Choanal and cloacal biological samples were performed by the use of swabs during oral and cloacal cavities inspection. Ninetytwo samples were collected from adult birds independently of sex, being 46 choanal and 46 cloacal swabs. The swabs were stored at $4^{\circ} \mathrm{C}$ in glass vials containing $3 \mathrm{~mL}$ of absolute ethanol, until processing (Raso et al., 2006).

DNA extraction followed a previous protocol (Ishizawa et al., 1991) with modifications. Swabs in absolute ethanol were transferred to $15 \mathrm{~mL}$ plastic tubes and submitted to homogenization by vortex for 2 minutes. Subsequently, the ethanol with biologic material in suspension were transferred to $2 \mathrm{~mL}$ microtubes and centrifuged at $20000 \times \mathrm{g}(15000 \mathrm{rpm})$ for 30 minutes at $4^{\circ} \mathrm{C}$. Then, with a precision pipette, the supernatant was discarded leaving $100 \mu \mathrm{L}$ of ethanol, with the precipitate. In this content, $10 \mu \mathrm{g}$ of glycogen (20 $\mu \mathrm{g} / \mathrm{mL}$, Invitrogen) and $300 \mu \mathrm{L}$ of a solution containing $6 \mathrm{M} \mathrm{Nal}, 13 \mathrm{mM}$ EDTA, 0,5\% N-lauroylsarcosina-sodium, $\mathrm{pH}$

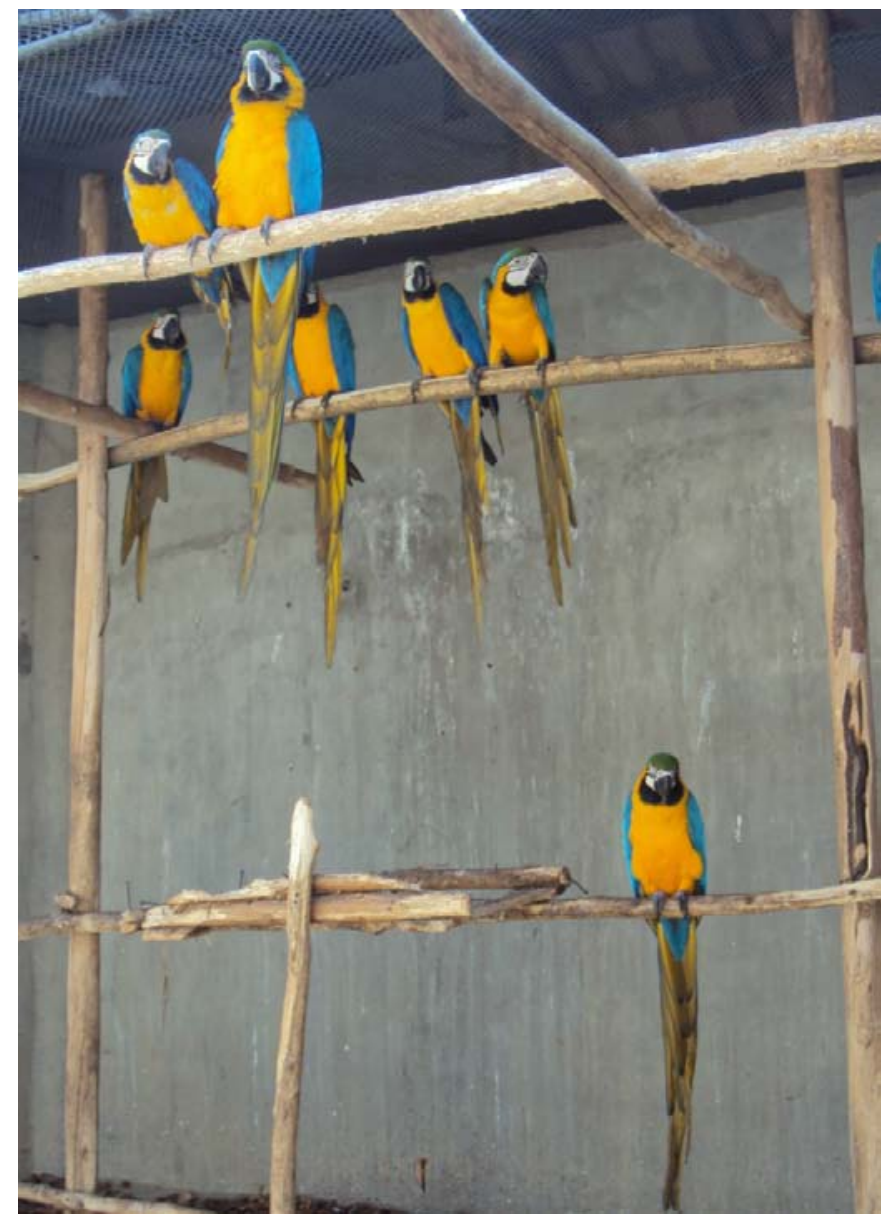

Figure 1: Collective squad of Ara ararauna (Aves: Psittaciformes) at Triage Center of Wild Animals of the Rio de Janeiro state, Brazilian Institute of Environment and Renewable Natural Resources, RJ, Brazil, 2011.

8.0, $26 \mathrm{mM}$ Tris- $\mathrm{HCl}$, were added. After homogenization, the microtubes were incubated in a water bath at $60^{\circ} \mathrm{C}$ for 15 minutes. It was added $400 \mu \mathrm{L}$ of absolute isopropanol at $-20^{\circ} \mathrm{C}$ with homogenization in a vortex, leaving the material resting for 15 minutes. After that, centrifugation was performed at 10000 x g (12000 rpm) for 5 minutes with subsequent discarding of supernatant. Addition of $1 \mathrm{~mL}$ of $40 \%$ isopropanol at the same temperature as the absolute one was done, followed by vortex shaking. It was centrifuged again at $10000 \times \mathrm{g}$ for 5 minutes, discarding the supernatant and, then, the microtube was left open to dry overnight in laminar flow hood. On the following day, the DNA was diluted in $50 \mu \mathrm{L}$ of Milli-Q water and was taken to the water bath at $37^{\circ} \mathrm{C}$ for 1 hour to dissolve the pellet. Every 15 minutes the microtube was shaken for homogenization of its contents, returning after this to incubation. After dilution, the material was stored at $-20^{\circ} \mathrm{C}$ until PCR analysis.

As positive control in this procedure, C. psittaci DNA was extracted from the quadruple feline vaccine (Felis QUANTUM ${ }^{\circledR} 4$ Intervet Schering-Plough) using the same extraction procedure described.

For PCR, it was followed previous technique (Sareyyupoglu et al., 2007), Laroucau et al., 2001). The primer pair used was CpsiA, 5'- ATGAAACATCCAGTCTACTGG-3' and CpsiB, 5'-TTGTGTAGTAATATTATCAAA-3', amplifying a fragment of 
300 base pairs (bp) (Sareyyupoglu et al., 2007). The concentration of each component of PCR consisted of 1X PCR buffer, $3 \mathrm{mM} \mathrm{MgCl}, 200$ $\mu \mathrm{M}$ of deoxynucleoside triphosphate (dNTPs), $1 U$ Taq DNA Polymerase, $0.2 \%$ dimethyl sulfoxide (DMSO) and $2 \mu \mathrm{M}$ of each primer plus $10 \mu \mathrm{L}$ of the diluted DNA, resulting in a total volume of $50 \mu \mathrm{L}$, supplemented with Milli-Q water or ultra pure. For all reactions, it was included a negative control with ultra-pure water instead of clinical specimen.

The amplification reaction was performed in a MG96 + model thermocycler (Long gene ${ }^{\circledR}$ ScientificlnstrumentsCo. Ltd.) using the following thermal cycles: an initial denaturation at $94^{\circ} \mathrm{C}$ for 2 minutes followed by 30 cycles of $94^{\circ} \mathrm{C}$ for 30 seconds, $50^{\circ} \mathrm{C}$ for 30 seconds and $65^{\circ} \mathrm{C}$ for 2 minutes, with a final extension at $65^{\circ} \mathrm{C}$ for 10 minutes (Sareyyupoglu et al., 2007).

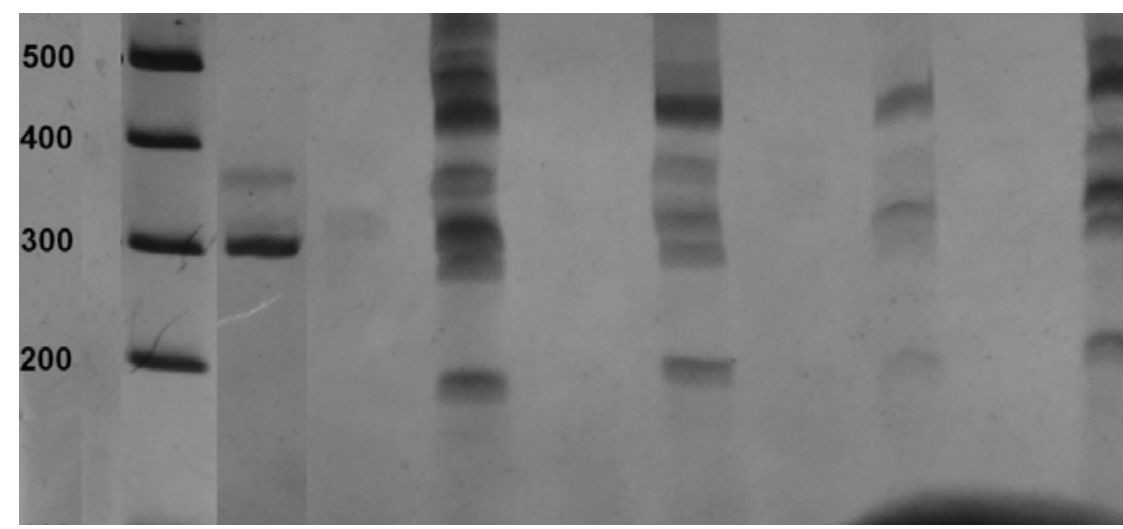

Figure 2: Positive bands of a DNA fragment of $300 \mathrm{bp}$ of Chlamydia psittaci amplified by Polymerase Chain Reaction on $6 \%$ acrylamide gel stained using $\mathrm{AgNO}_{3}$ solution. From left to right: $100 \mathrm{bp}$ DNA ladder, positive control (300 bp) and negative results from coanal swabs intercalated with DNA bands from cloacal ones of blue-and-gold macaws (Ara ararauna; Aves: Psittaciformes) from Triage Center of Wild Animals of the Rio de Janeiro state, Brazilian Institute of Environment and Renewable Natural Resources, RJ, 2011. In the end, the negative control. Some nonspecific bands are also visualized at cloacal swabs samples.
The PCR products were visualized on $6 \%$ polyacrylamide gel stained with silver nitrate $\left(\mathrm{AgNO}_{3}\right)$ solution after electrophoresis in $1 \times$ TBE $100 \mathrm{~V}$, with $18 \mathrm{~W}$ and $49 \mathrm{MA}$ for 1 hour.

For the statistical analysis, the study aimed the probabilistic frequency response, by conducting a survey, with the generation of the agent's frequency in the group evaluated. Data were analyzed by simple linear regression, multiple logistic regression, Fisher's Exact Test and Risk Analysis.

\section{Results and discussion}

\section{Frequency of C. psittaci in the macaws evaluated}

From the tested birds, 50\% (23/46) were PCR positive for Chlamydia psittaci DNA by cloacal swab. Among these cloacal positive birds, $26.09 \%$ (12/23) were also positive by choanal swab (Table 1).

Table 1: Polymerase Chain Reaction (PCR) from cloacal and choanal swabs in Ara ararauna (Aves: Psittaciformes), at the Triage Center of Wild Animals/ Rio de Janeiro / Brazilian Institute of Environment and Renewable Natural Resources, Brazil, from July to October 2011

\begin{tabular}{ccc}
\hline PCR Results & \multicolumn{2}{c}{ Site of material collection for PCR } \\
\cline { 2 - 3 } & cloacal swab & choanal swab \\
\hline Positive & $23(50 \%)$ & $12(26.09 \%)$ \\
Negative & $23(50 \%)$ & $34(73.91 \%)$ \\
Total & $46(100 \%)$ & $46(100 \%)$ \\
\hline
\end{tabular}

Fisher's Exact Test: $p<0.05$

$\mathrm{OD}=2.833 ; \mathrm{IC}(1.180$ to 6.804$)$

The assessment in relation to sample collecting sites yielded significant difference $(p<0.05)$ by Fisher's Exact Test. The probability of bacterium DNA detecting by cloacal swab was 2.83 times greater than a choanal swab under PCR: Odds Ratio $=2.83, \mathrm{Cl}$ (1.180 to 6.804). Positive DNA bands are presented in Figure 2. Also in this figure, some nonspecific bands can be visualized at cloacal swabs samples.
The higher frequency of $C$. psittaci in cloacal swabs compared to choanal ones suggests longer time post exposure to the bacteria, once initial infections tend to stay primarily in the respiratory tract, being subsequently eliminated in feces (Andersen, 1996). These results corroborate to previous report (Santos et al., 2014; Raso et al., 2006) where C. psittaci semi-nested PCR detection in psittacine birds was more frequently in cloaca samples than oropharynx and tracheal ones. However, in another study (Andersen, 1996), it was found greater isolation rate of C. psittaci in cockatiels (Nymphicus hollandicus) from pharyngeal swabs $(80.4 \%)$, while fecal and cloacal resulted in positivity of $45.1 \%$ and $37.3 \%$, respectively.

It should be highlighted that as the agent has intermittent fecal shedding (Harkinezhad et al., 2009), the detection of bacterial DNA is naturally influenced by the post-exposure time and therefore negative individuals can also harbor the bacterium . Since Ara ararauna individuals were kept in collective places, it was expected that all birds had already been exposed to $C$. psittaci, once the transmission takes place by proximity, mainly by inhalation and sometimes by ingestion of contaminated material (Harkinezhad et al., 2009).

The prevalence of infection varies among free-living and captive birds, being higher when many birds are confined in small areas or when there are frequent changes in the flock (Sareyyupoglu et al., 2007). These features corroborate to the high positivity found in this study, since at the CETAS/IBAMA/RJ birds were allocated in collective places with turnover and constant arrival of new individuals, besides the proximity to free-living birds, with enclosures protected only by screens in their sides. Similar situation of collective infection it was reported in an outbreak of chlamydiosis in Psittacidae birds at CETAS / IBAMA/MG, where the birds were kept in collective aviaries with frequent arrival of rescued animals and proximity of pigeons and free-living birds (Eco et al., 2009).

\section{Findings to the General Clinical Evaluation}

Abnormal feathering was found in $13.04 \%$ (6/46) of the examined macaws, through visualization of areas with loss of feathers, and two of them were positives to C. psittaci. Body scores found ranged from 01 to 03 , being $2.17 \%$ (1/46) the percentage 
for cachectic, $47.83 \%$ (22/46) for thin and $50.00 \%(23 / 46)$ for normal. In fact, in birds, C. psittaci produces a systemic infection (Sareyyupoglu et al., 2007) and can show changes in plumage and weight loss (Gerlach, 1994). The plumage changes may have different etiologies: bacterial, viral, parasitic or behavioral (Cubas e Godoy, 2006). Despite the two C. psittaci positive macaws with plumage changes in this study, the multifactorial etiology of these findings do not allow to affirm their association with C. psittaci infection. In relation to the body condition, from the 23 C. psittaci positive macaws, 10 were regarded as thin, body score 02 . However, 12 negative macaws also had score 02 , which opens the possibility of coexistence of other factors acting together toward weight loss in birds. Therefore, the slimming of positive macaws may not be definitely associated to C. psittaci. The finding that 13 positive macaws had score 03 (normal), and the fact of many Psittacidae birds may not show clinical signs when chronically infected, corroborates this assertion (Harkinezhad et al., 2009).

The body temperature during contention ranged from 40 to $42.4^{\circ} \mathrm{C}$, with an average of $41.40^{\circ} \mathrm{C} \pm 0.62^{\circ} \mathrm{C}$. The PCR positive individuals had an average of $41.39^{\circ} \mathrm{C} \pm 0.58^{\circ} \mathrm{C}$, and for negative ones, $41.41^{\circ} \mathrm{C} \pm 0.67^{\circ} \mathrm{C}$. Therefore, there was no suggestion of hyperthermia (Rodolakis e Mohamad, 2010), since in most birds the cloacal normal temperature is around 41.7 to $44.4^{\circ} \mathrm{C}$ (Greenacre e Lusby, 2010). Regarding the possibility of hypothermia (Gerlach, 1994), there were no substantial differences between the lower temperatures of positive and negative birds, with a difference of only $0.1^{\circ} \mathrm{C}$ between the lowest temperature recorded in the first group compared to the lowest in the second one. However, members of the Psittacidae family, when manually contained may raise its cloacal temperature in $2.3^{\circ} \mathrm{C}$ during the first 15 minutes of manipulation which yields significant difference in the first four minutes of containment (Greenacre e Lusby, 2010). So it would be expected higher temperatures in relation to those found in individuals whose measurements were below $41^{\circ} \mathrm{C}$.

It was observed an association between temperature $(Y)$ and body score $(X)$ risk factors $(p<0.05)$ by simple linear regression: $Y=40.86+0.22(X)$, where the coefficient of determination $\left(R^{2}\right)$ was $3.77 \%$. The temperature worked as predictor, explaining $3.77 \%$ of body score variations. So as higher the temperature, higher is the score of the bird. However, there was no association among PCR positivity (presence of DNA bacterial in cloacal or choanal swab) and body score plus temperature $(p>0.05)$ by multiple logistic regression analysis.

No birds had clinical changes in nasal, oral or hearing cavities. The majority of macaws, $97.83 \%$ (45/46), had no change in clinical ophthalmic cavity. One individual presented a corneal scarring process, indicative of old injury, possibly not related to their current clinical status neither a Chlamydia infection. No one had notable changes in cloacal cavity, however, during the collection of the cloacal swab it was observed greenish-yellow cloacal content in three individuals; greenish-yellow cloacal mucous content in an individual and green one in another. Similar, macroscopic evaluation of faeces and urine for the group detected changes suggestive of chlamydiosis: green faeces only or green, watery and pasty faeces and increased amount of urate. All the changes found in faeces and urine had been described in the literature (Gerlach, 1994), as well as those evidenced in cloacal swabs, and C. psittaci DNA was detected in four out of five birds with changes showed in swabs.

In general, $34.78 \%(8 / 23)$ of $C$. psittaci positive macaws yielded no significant clinical changes. In fact, Psittacidae birds commonly exhibit a chronic form of the disease (Harkinezhad et al., 2009). In this context, Raso et al. 2002 and Grespan 2009 also showed asymptomatic infections; and it has been reported death without previous clinical signs in positive psittacines (Eco et al., 2009).

It should be noted that, since Psittacidae birds are the largest reservoir of $C$. psittaci, particularly under captive conditions (Harkinezhad et al., 2009), and being Brazil the richest country in these birds (Sick, 1997), it is expected higher prevalence of this disease in this country. Therefore, comprehensive studies are needed in relation to pet birds, wild populations and environmental contamination that they generate.

Ultimately, it becomes necessary to carry out further studies in favor of getting the real situation of the pathogen spread in Brazil, in order to assess what should be the best solutions and the optimal interventions to be performed. It must be emphasized the need of research on humans, with performance of differential diagnoses for respiratory and neurological diseases, as well as the need of study performance about the zoonotic transmission from pet and free-living birds, especially with those have been adapted to urban centers.

\section{Conclusion}

In this study, PCR was efficient in detecting Chlamydia psittaci in captive macaws (Ara ararauna), yielding a positivity of $50 \%$ in a premises of 46 macaws at CETAS / IBAMA, RJ. Detection from cloacal swabs was more indicated than choanal ones, with a probability of detection 2.83 times higher for cloacal site.

There was no relationship between body condition score, temperature variations and PCR positivity to C. psittaci. PCR positivity to $C$. psittaci was found also in asymptomatic macaws. Therefore, the quarantine in wildlife conservation and support centers, also the care with hygiene and individual protection for humans who deal with the animals, should be strictly followed even in the absence of clinical signs.

\section{Acknowledgements}

The authors are grateful to CETAS / IBAMA/RJ for the permission to work with their animals and for the availability of its employees for the management of them during the search.

To the CAPES for research fellowships provided. 


\section{References}

ANDERSEN, A.A. Comparison of pharyngeal, fecal, and cloacal samples for the isolation of Chlamydia psittaci from experimentally infected cockatiels and turkeys. Journal of Veterinary Diagnostic Investigation, v. 8, p. 448-450, 1996.

BIRDLIFE INTERNATIONAL. IUCN Red List for Birds 2012. Birdlife database (http://www.birdlife.org). Accessed 12 january 2012.

CUBAS, Z.S.; GODOY, S.N. Algumas doenças de aves ornamentais, 2006. (http://wonderfullglosters.110mb.com). Accessed 12 de january 2012.

ECO, R.; PREIS, I.S.; MARTINS, N.R.S.; VILELA, D.A.R.; SHIVAPRASAD, H.L. An outbreak of chlamydiosis in captive psittacines. Brazilian Journal Veterinary Pathology, v. 2, p . 85-90, 2009.

EFE, M.A.; MARTINS-FERREIRA, C; OLMOS, F.; MOHR, L.V.; SILVEIRA, L.F. Diretrizes da Sociedade Brasileira de Ornitologia para a destinação de aves silvestres provenientes do tráfico e cativeiro. Revista Brasileira de Ornitologia, v. 14, p. 67-72, 2006.

GERLACH, H. Chlamydia. In: RITCHIE, B.W.; HARRISON, G.J.; HARRISON, L.R. Avian Medicine: Principles and Application. Florida: Wingers, 1994, p. 984-996.

GREENACRE, C.B.; LUSBY, A.L. Physiologic responses of Amazon parrots (Amazona species) to manual restraint. Journal of Avian Medicine and Surgery, v. 18, p.19-22, 2004.

GRESPAN, A. Clamidiose em calopsitas (Nymphicus hollandicus): perfil proprietário e ensaio terapêutico. 2009, 111p. Dissertation (mestrado). Universidade de São Paulo, São Paulo, 2006.

GUO, W.; LI, J.; KALTENBOECK, B.; GONG, J.; FAN, W.; WANG, C. Chlamydia gallinacea, not C. psittaci, is the endemic chlamydial species in chicken (Gallus gallus). Scientific Reports. v. 18, n. 6, p.19638, 2016.

HARKINEZHAD, T.; GEENS, T.; VANROMPAY, D. Chlamydophila psittaci infections in birds: a review with emphasis on zoonotic consequences. Veterinary Microbiology, v. 135, p. 68-77, 2009.

INSTITUTO BRASILEIRO DE MEIO AMBIENTE E RECURSOS RENOVÁVEIS (IBAMA). Centros de Triagem de Animais Silvestres - CETAS. IBAMA database (http://www.ibama.gov.br/ fauna/cetas.php). Accessed 12 de january de 2012.

INSTITUTO BRASILEIRO DE MEIO AMBIENTE E RECURSOS RENOVÁVEIS (IBAMA). Instrução Normativa 179, 25 June 2008.

INSTITUTO CHICO MENDES DE BIODIVERSIDADE (ICMBIO). Plano de soltura monitorada de arara-azul-de-lear, 2004. ICMBIO database (www4.icmbio.gov.br). Acessed 13 january 2012.

ISHIZAWA, M.; KOBAYASHI, Y; MIYAMURA, T; MATSUURA, S. Simple procedure of DNA isolation from human serum. Nucleic Acids Research, v.19, p.5792, 1991.
KALETA, E.F.; TADAY, E.M. Avian host range of Chlamydophila spp. based on isolation, antigen detection and serology. Avian Pathology, v. 32, p. 435-461, 2003.

LAROUCAU, K.; SOURIAU, A.; RODOLAKIS, A. Improved sensitivity of PCR for Chlamydophila using pmp genes. Veterinary Microbiology, v. 82, p. 155-164, 2001.

RASO, T.F.; SEIXAS, G.H.; GUEDES, N.M.; PINTO, A.A. Chlamydophila psittaci in free-living Blue-fronted Amazon parrots (Amazona aestiva) and Hyacinth macaws (Anodorhynchus hyacinthinus) in the Pantanal of Mato Grosso do Sul, Brazil. Veterinary Microbiology, v.117, p. 235-241, 2006.

RASO, T.F.; GODOY, S.N. ; MILANELO, L. ; DE SOUZA, C.A. ; MATUSCHIMA, E.R. ; ARAÚJO JÚNIOR, J.P. ; PINTO, A.A. An outbreak of chlamydiosis in captive blue-fronted Amazon parrots (Amazona aestiva) in Brazil. Journal of Zoo and Wildlife Medicine, v. 35, p. 94-96, 2004

RASO, T.F.; BERCHIERI, J.R.; PINTO, A.A. Evidence of Chlamydophila psittaci infection in captive Amazon parrot in Brazil. Journal of Zoo and Wildlife Medicine, v. 33, p. 118-121, 2002.

RODOLAKIS, A.; MOHAMAD, K.Y. Zoonotic potential of Chlamydophila. Veterinary Microbiology, v. 140, p. 382-391, 2010.

SACHSE, K.; LAROUCAU, K.; RIEGE, K.; WEHNER, S.; DILCHER, M.; CREASY, H.H.; WEIDMANN, M.; MYERS, G.; VORIMORE, F.; VICARI, N.; MAGNINO, S.; LIEBLER-TENORIO, E.; RUETTGER, A.; BAVOIL, P.M.; HUFERT, F.T.; ROSSELLÓMÓRA, R.; MARZ, M. Evidence for the existence of two new members of the family Chlamydiaceae and proposal of Chlamydia avium sp. nov. and Chlamydia gallinacea sp. nov. Systematic and Applied Microbiology. v. 37, n. 2, p. 79-88, 2014.

SANTOS, F.; LEAL, D.C.; RASO, T.F.; SOUZA, B.M.P.S.; CUNHA, R.M.; MARTINEZ, V.H.R.; BARROUIN-MELO, S.M.; FRANKE, C.R. Risck factors associated with Chlamydia psittaci infection in psittacine birds. Journal of Medical Microbiology, v. 63, p. 458463, 2014.

SAREYYUPOGLU, B.; CANTEKIN, Z.; BAS, B. Chlamydophila psittaci DNA detection in the faeces of cage birds. Zoonoses and Public Health, v. 54, p. 237-242, 2007.

SICK H. Ornitologia Brasileira. Rio de Janeiro: Nova Fronteira, 1997, p. 912.

SIGRIST T. Aves do Brasil - Uma Visão Artística. São Paulo: Avisbrasilis, 2006, p. 672.

SZYMAŃSKA-CZERWIŃSKA, M.; NIEMCZUK K. Avian Chlamydiosis Zoonotic Disease. Vector-Borne and Zoonotic Diseases. v. 16, n. 1, p. 1-3, 2016. 